\title{
Sustainable Economy: Do Not Use The Debt Widely ${ }^{1}$
}

\author{
V. Zuev, E. Ostrovskaya, E. Frolova
}

Vladimir Zuev - PhD, Professor of Economic Sciences, National Research University Higher School of Economics; 20 Myasnitskaya, 101000 Moscow, Russian Federation; E-mail: vzuev@hse.ru

Elena Ostrovskaya - PhD, Associate Professor, School of World Economy, National Research University Higher School of Economics; 20 Myasnitskaya, 101000 Moscow, Russian Federation; E-mail: eostrovskaya@hse.ru

Ekaterina Frolova - Assistant at the World Economy Department School of World Economy, National Research University Higher School of Economics; 20 Myasnitskaya, 101000 Moscow, Russian Federation; E-mail: esfrolova@icloud.com

In this article we consider the issue of debt, which became a global concern, within another global conceptin the context of sustainable development and economic growth. More and more attention is paid to this concept due to urgent necessity for coordination of policies at both national and global levels. The predominant theoretical thinking tends to underestimate the risks. Although a lot have been made towards improving global financial stability after the recent crisis, the risks remain high as new threats and challenges emerge, and the global financial system is still unable to respond to them adequately. Having considered the banking regulation innovations from the perspective of financial security and inclusiveness, we come to conclusion that the global financial reforms are being conducted in the right direction, and the system became more secure, however, not yet sufficiently sustainable. The other idea we come up with is that implementation of financial transaction tax as a tool to discourage excessive speculation without impeding other economic activities, which is the argument opponents of the tax appeal to, seems to be socially responsible measure working for financial stability at the same time. Finally, we also assume that steadily increasing nonfinancial sector debt of the leading economies presents a serious challenge to global financial stability and to sustainable growth. Estimates of the threats to the world economy from unprecedented debt at all levels of economic system are largely inadequate. Effective and inclusive measures to reduce it have not been yet developed. Therefore, the issue of increasing indebtedness should be tackled accordingly. Otherwise, the world economic system appears to become very fragile and unsustainable under the burden of financial imbalances and emerging risks.

Key words: nonfinancial debt; financial stability; sustainable and inclusive growth; debt governance; financial transaction tax

For citation: Zuev V., Ostrovskaya E., Frolova E. (2017) Sustainable Economy: Do not use the Debt Widely. International Organisations Research Journal, vol. 12, no 4, pp. 68-90 (in Russian and English). DOI: 10.17323/1996-7845-2017-04-68

${ }^{1}$ The editorial board received the article in July 2017.

Modified version of the article was placed on June 2017 on the G20 web site 'Insights - literature from the Think tanks' in the course of the preparation for the G 202017 Summit in Germany. Available at: http:// www.g20-insights.org/related_literature/vladimir-zuev-elena-ostrovskaya-ekaterina-frolova/ (accessed 17 October 2017). 


\section{Introduction}

On September 25, 2015, the leaders of the 193 UN Member States adopted a 15-year program, entitled "Transforming Our World: 2030 Agenda for Sustainable Development," which contains 17 Sustainable Development Goals (SDGs) and 169 targets. The following year, the G20 met and adopted the G20 Action Plan on the SDGs, in which the G20 members committed to meeting these goals through "collective and individual efforts, at home and abroad" with a "focus on sectors and themes of the Agenda where the G20 has a comparative advantage and can add value as a global forum for economic cooperation."

Since the start of the Agenda's implementation, the G20 has placed global sustainable development at the center of its activities. However, so far, no country has achieved sustainable development from the standpoint of its economy, financial sector, social sphere or the environment. Over the next few years, decisive action in several specific areas will prove critical for the G20 countries if they hope to reach the SDGs. In this article, we want to treat the issue of financial stability as a key factor in implementing the Action Plan.

Waves of financial instability are rising in the global economy. Which segment of the market will be the next to confront a rogue wave, and to what extent are national and global regulators prepared for future shocks? Many new initiatives were launched recently to enforce global financial supervision and governance. However, risks remain high. New threats emerge and the world economy remains far from resilient enough to withstand the likely shocks arising from growing financial imbalances. To navigate this environment successfully, policymakers must prepare adequately or steer us towards safe waters.

Recently the IMF published a report on global non-financial sector debt (IMF, 2016). The figures demonstrate a sharp rise in both public and private sector debt, which the Fund expected to reach new heights by the year 2017. So far, regulators have done what they could to lessen financial risks arising from the banking sector, although the new parameters of the system still need a lot of improvement, especially if they hope to promote socio-economic inclusiveness, a key theme of the SDGs. The record levels of non-financial sector debt, in our view, represent a serious new challenge if the SDGs are to be implemented. Governments must stick to financial discipline in a more responsible way. A correct assessment of new risks is needed to secure the system and make it sustainable.

First, we will make an assessment of innovations in banking regulation from the perspective of financial security and inclusiveness ${ }^{2}$. Our conclusion is that the sector hasn't proven that it's sufficiently sustainable. Then we disclose the remaining deficits of the regulatory system, discovering emerging risks to stability and growth from the non-financial sector, and suggest more arguments for the introduction of an adequate regulatory response. Additionally, we'll detail how the system appears to have become very fragile and unsustainable.

${ }^{2}$ The authors acknowledge 2016-17 support of the World Economy and International Affairs Faculty of the National Research University Higher School of Economics. 


\section{Dealing with Bank Debt}

The global financial crisis revealed a systemic deficit of financial regulation at the global level among all financial institutions, especially with respect to banks. This came as the result of a long process of the "diffusion of power in favor of private actors" in the financial sector [Underhill, Zhang, 2008, p. 535-554]. Insufficient regulation at the global level made the system extremely unstable and risky. Uncontrolled, exponential growth within the financial sector and its rapid globalization have led to an equally rapid increase in endogenous challenges. Some of the key risks that we would like to outline to assess challenges to global economic governance were the following:

- Overleveraged banks provided too much credit, which lead to speculative bubbles in the US sub-prime mortgage sector and other countries' real estate markets and a huge effect of 'toxic waste' derivatives;

- Bank's risk management strategies proved ineffectual;

- Too much speculation activity. Bankers are losing interest in lending to real sector companies, faced with high incomes from speculation and modest incomes from real sector investments;

- Troubled lenders and other financial companies even after receiving emergency funding, rewarded executives generously and issued them exorbitant bonuses;

Looking at the list, we can see that most of the risks originated in the banking sector. Normally banks are supposed to stimulate growth, but many risks resulted from banking activities. In general, we can conclude that the financial sector became estranged from industry as banks ceased to play a beneficiary role in the financing of industrial activity.

The core element of financial governance is banking regulation. In theory, banking services should provide an important link between the financial and the real sector in securing economic growth. In reality, the banking sector has, in itself, become a source of risk multiplication, including active speculative activity, resulting in financial "bubbles," and increasing the gap between the real and the financial sector. Unsecured banking operations have started to threaten growth instead of stimulating it. The intermediator link between the banks and the real sector is becoming less vital to the banks. The financial sector in itself becomes a focus of banking activities. This sector begins to live its own life. That has become a challenge for regulators; to bring banks closer to producers in order to stimulate economic growth again. As banks appear to be the key contributors to financial instability, the big question is how to diminish that risk.

Banks are expected to be the cornerstone of financial stability. If they are at risk or deemed "too big to fail," the governments jumps in to save them using public funds in order to protect customers. In doing so, they help banks by redistributing money from these same customers, the taxpayers.

Speculative operations are the source of highest risk for banks; simultaneously, however, they offer the greatest profit margins. Thus, it seems unrealistic to separate speculative investment from lending activity. Banks will always be tempted to engage in risky operations in order to generate high returns. The measures which have been taken at the national and global level to increase capital requirements, extend monitoring and 
perform stress tests are all vital, but they are not enough to guarantee that banks remain solvent. The most relevant measure to assure financial stability is to introduce a tax on financial institutions' speculative operations and to establish a rescue fund for banks at their own expense. Our argument is that this measure combines lower risks for the financial system with international commitments to promote inclusiveness and strong, balanced growth.

A tax in one country or in a small group of countries will be not sufficient. It will only bring a solid and visible effect if introduced at a global level. Thus, a global institution could and should provide an appropriate platform for such an initiative. The G20 is a strong contender for this role, as it has an adequate global format for the introduction of such a tax. It would benefit the G20, upgrade financial stability and provide needed public support to global governance institutions. Surprisingly, the idea is not among the top priorities of the global agenda, although the cost is low for the stakeholders, because of the low rate of the tax proposed. This paper strongly supports the idea of introducing such a financial transaction tax. The authors provide more analytical arguments in this regard and want to increase public and academic awareness of the necessity of such a measure.

When the G20 convened in China, it placed a high priority on several specific development goals: to "eradicate poverty, achieve sustainable development and build an inclusive and sustainable future for all," and "continue to promote strong, sustainable and balanced growth." If these Goals are to be achieved, the financial sector must undergo drastic changes. Another aspect of the issue is that most of the risks are global or regional in origin but are dealt with at the national level. The financial system lacks control at the global level. Some risks are supervised, but it is mostly done by informal institutions with no legally binding commitments. Financial markets became transnational many decades ago, but formal regulation and supervision have mostly remained national. Because of these gaps, the system has become either self-regulated or poorly regulated. This has been promoted by the liberalization of financial markets by states, and this same liberalization has been used as a tool to attract investment [Tsingou, 2003, p. 8]. For this reason, the need for global financial governance is more urgent than ever. Attempts to create an independent system of global supervision have encountered opposition from nation-states and from the banking community. They are interested in 'carte blanche', and are not supporting the establishment of a system of global financial governance.

Better global financial governance means setting up a coherent system of legitimate institutions, using adequate and effective regulation instruments, relying on efficient methods of monitoring and control over the financial networks, and ensuring that the interest of the people remains safeguarded with these measures in place. In this article, we try to analyze the most important of these aspects to provide the grounds for the assessment of the emerging system's inclusive function.

Many scholars support stronger international regulation [James, Patomak, 2006]. What kind of regulation do we need and what should be regulated?

Theoretical concepts of global governance are well developed by many scholars. The link between formal and informal institutions is represented by the concepts of ma- 
jor informal institutions (like the G8 and G20) governing either through multilateral formal organizations [Kokotsis, 1999] or against them [Kirton, 2004], or without them [Bayne, 2000]. The authors of this study advance another vision of this link, presuming that within the last decade an emerging system of interlinks among different institutions can be defined like members of an orchestra, each of whom has his own sheet of music but remains part of a coordinated effort to play the tune of financial stability. We assess the process of setting up new financial institutions and that of igniting new life into traditional ones, resulting in the emergence of an interlinked system of global financial governance institutions. During the post-crisis years, financial architecture has been reassessed and regulatory mechanisms have undergone radical change at the international level. Only a decade ago, authors who explored the financial regulatory system never mentioned a single global supervisory institution in their works [Chung-Hua, 2006].

In this study, we depart from the assumption ${ }^{3}$ that a large part of the financial regulation has been initiated at the global level, strengthening global financial governance during the post-crisis decade and making it sound like an orchestra.

\section{Selecting Proper Instruments to Assure Inclusive and Sustainable Growth}

The starting point in making the system of financial regulation more efficiently targeted to promote inclusive and sustainable growth is making banks more accountable. Regulations regarding capital requirements for banks came into effect in all 27 jurisdictions that are members of the Basel Committee on Banking Supervision. When the banks heed these provisions, it enhances the reliability of the system, but this is not enough. The Basel III prescriptions, even if applied in full, are insufficient to build an effective system of control over the banking sector [Gros, 2013]. Among the deficiencies in the existing mechanism is the fact that banks use internal models to calculate capital requirements, there's a lack of disclosure and the minimum leverage ratio is insufficient [KPMG, 2013]. Another difficulty is the growing discrepancy in national approaches to the Basel standards' implementation. The Basel IV framework could provide solutions to these issues. The Bank of International Settlements (BIS) is also trying to catch up with these deficits by advancing different solutions [Bank for International Settlements, 2015]. The Basel Committee does a lot to promote the adopting of new standards and recommend best practices in banking supervision. The Financial Stability Board encourages the adherence by all jurisdictions to regulatory and supervisory standards on information exchange [FSB, 2010]. The Economic Stability Council pushed forward the introduction of International Financial Reporting Standards (IFRS). This is particularly important, as states are reluctant to transfer their powers to global regulators [Baxter, 2011]. The ESC's tasks, to simplify and improve international standards of financial reporting, and harmonize financial listing standards, were

${ }^{3}$ Zuev V., Ostrovskaya E. Setting up a system of global financial supervision. Review of international organizations, 2016, no 4, pp. 106-126. 
conducted in cooperation with the International Accounting Standards Board (IASB) as well as with national institutes.

The global institutions' process of creating new, globally applicable packages of regulations is systematic and consistent. For example, in January 2016 the next set of changes in requirements for banks regarding market risk revaluation was adopted; in February 2016, two more documents were published - the Guide to Anti-Money Laundering and Recommendations on Account Opening Procedures. And so it goes on; this regularity, continuity and consistency, generated at a global level within the last decade, provides for a solid base to avoid erratic and conflicting national legislative activity, which is where and how a sound new international financial order might be set up.

There are many other issues to be tackled in order to comply with the G20-backed UN SDGs, including concepts such as "too big to fail" as well as "shadow banking systems." They all lie within the competence of international institutions [Tobias, 2014]. 'Too big to fail' banks present a special case for social responsibility and inclusiveness. In this particular case, an international regulatory response to the issue is very important.

In the year 2013, a methodology to identify systemically important global insurance companies (G-SIICs) and an updated technique of revealing global systemically important banks (G-SIBs) were published. Using this basis, the list of G-SIBs was composed (it included 28 G-SIBs) and an initial list of G-SIICs has been compiled and is updated annually starting from November 2014. Financial institutions included in these two lists are obliged to meet higher requirements and are subject to more rigorous supervision. Plans for the settlement of insolvency were developed for them. The liquidity adequacy requirements for $28 \mathrm{G}-\mathrm{SIBs}$ were also developed and in most cases, the G-SIBs increased capital before the deadlines. Additional stringent requirements for liquidity adequacy have applied to G-SIBs since 2016 with their gradual full introduction by 2019.

Late in 2014, the FSB put forward an initiative increasing big banks' accountability in order to upgrade the risk absorption role of the global banking system [Bruno, Song Shin, 2014]. The proposal was to oblige the global, systemically important banks (GSIBs) to have additional reserve assets so that the losses are not shifted onto taxpayers' shoulders in the event of an emergency. On November 11, 2015, following a quantitative impact assessment, the Financial Stability Board finalized total loss absorbing capacity (TLAC) and minimal requirements for G-SIBs. Although the initiative was endorsed by the G20 summit, the implementation mechanisms have yet to be detailed at a national level. Nevertheless, this is a move in the right direction - banks should bear most of the responsibility themselves and cover the cost of overcoming eventual risks.

On October 12, 2016, new standards for internationally-active banks (both G-SIBs and non-G-SIBs) regarding TLAC holdings was published by the FSB, according to which banks must deduct their TLAC holdings that do not otherwise qualify as regula-

${ }^{4}$ FSB includes in this category, among others, money market funds (MMFs), structured finance vehicles, broker-dealers, finance companies, financial holding companies, hedge funds and other investment funds. For more details, see A Police Framework for Strengthening Oversight and Regulation of Shadow Banking Entities and a Policy Framework for Addressing Shadow Banking Risks in Security Lending and Repos. Financial Stability Board. Available at: http://www.fsb.org/wp-content/uploads/c_130129y.pdf 
tory capital from their own Tier 2 capital. This reduces a significant source of contagion in the banking system. The standard also reflects changes to Basel III specifying how G-SIBs must consider the TLAC requirement when calculating their regulatory capital buffers [FSB, 2016].

In 2015, the Financial Stability Board launched a peer review on the implementation of the policy framework for financial stability risks posed by non-bank financial entities ("other shadow banking entities") [FSB, 2015]. The objective of the review was to evaluate the progress made by jurisdictions in implementing the principles, in order to reduce the prevalence of shadow banking and promote regulatory compliance. Peer review appears as another instrument to ensure the establishment of a more reliable system. In accordance with the provisions of the Charter of the FSB, the member countries are obliged to periodically implement the Financial Sector Assessment Program (FSAP) of the IMF and World Bank. They have to present country surveys, which contain an evaluation of the degree of implementation of international standards. The work to provide these reports enhances compliance.

One of the problems is that most of the global institutions' decisions are recommendatory, although a relatively high level of compliance appears as an extraordinary feature of global financial governance [Brummer, 2012]. Expanding the controlling functions of the international institutions and obliging the national and international actors to make regular reports on their activities substantially helps increase the influence of internationally-acknowledged norms. The global institutions set up a certain standard for financial regulation. Moreover, they exert soft power to enforce this regulatory framework for financial institutions. For example, if the financial institutions concerned do not fully comply with the provisions of Basel III (liquidity coverage ratio or the net funding ratio) they may not be allowed access to the major stock exchange platforms. In this way, stimulus to respect the new international prescriptions is created. Some bankers claim they are not ready to fulfill these recommendations, describing them as too exacting. Nevertheless, the adopted global standards are eventually implemented by most countries, even if this is implemented by the banking sector somewhat grudgingly. Therefore, it is crucial that the chosen global standard should promote inclusive and sustainable growth.

Another instrument of financial governance is the introduction of sanctions based on stress tests. Conducting stress tests on a regular basis is an innovation in global governance. The terms of reference of the stress tests undertaken by the FSB stipulate the issuance of a warning, if non-compliance is revealed for the first time. The inclusion of a member-state or its banking institutions in "grey" and "black" lists, in the event of repeat non-compliance, entails the imposition of sanctions by the Financial Stability Board. Thus, FSB members are involved in the formulation of general rules, norms and procedures, selecting proper instruments of implementation and providing for supervisory and controlling functions, thus assuring compliance with the adopted recommendations. In November 2015, the FSB published the first report on the Implementation and effects of the G20 financial regulatory reforms. Implementation of the Basel III reforms for the bank capital and liquidity requirements took place ahead of schedule. 
Summing up the overview of the adopted instruments, we can conclude that a vast number of new measures appear: monitoring procedures, checks and stress tests, new standards of reporting and accounting, new risk-management techniques and the exchange of best practices, new capital requirements, etc. What is missing?

There are two big problems which remain unresolved. Market speculations remain very attractive for the banks. Consequently, the risk of dangerous financial bubbles emerging remains high. If they occur, they could put banks at risk of insolvency, necessitating that governments earmark funds from national budgets to provide them with liquidity. As in the past, there is no fund financed by the bankers themselves that could rescue banks in the event of necessity, but a rational solution appears to be evident.

\section{Financial Transaction Tax - Inclusiveness, Social responsibility and Financial Stability}

Is the current contribution from the financial sector to the financial stability of the majority of their customers fair enough? The ongoing reforms since the outbreak of the global financial crisis do not solve one key problem, namely, the enormous cost of rescuing the financial sector in the event of a looming economic collapse brought about by speculative euphoria. These costs are taken on, to a large extent, by governments and the taxpayer; meanwhile, speculators and the institutions that facilitate their activity benefit almost exclusively from risky financial behavior when it proves successful.

Our study aims to outline the necessity for the regulators to undertake concrete policy measures to meet the challenge of maintaining global financial stability, in line with international social responsibility objectives. If we think about market instruments, taxation is the first thing to come to mind. It could serve two goals: discouraging speculation and providing a source of financing for a fund that would rescue banks in trouble at their own expense. Thus, it would reflect the UN and G20 objective of promoting an inclusive, sustainable society.

The discussion on the introduction of various forms of financial taxation has a long history. In 1936, John Maynard Keynes wrote: "The introduction ofa substantial Government transfer tax on all transactions [on Stock Exchanges] might prove the most serviceable reform available with a view to mitigating the predominance of speculation over enterprise in the United States" [Keynes, 1961].

The regulatory system needs adequate mechanisms to discourage excessive speculating. Basel III provides for stronger capital requirements, assuring more responsibility by the banks, but does little to reduce speculation. Speculation continues to flourish in the financial sector amid inflated values, while financing is less available in the real sector economy.

In 2009, Paul Krugman published an article, "Let's make banking boring again." [Krugman, 2009] He argued that the banking industry which emerged from the US Great Depression was tightly regulated. Banks served as intermediators and banking was "boring." After 1980, however, many of the regulations on banks were lifted, and banking became exciting again. That was the moment when speculative activity became great. 
Debts began rising rapidly, and the financial industry exploded in size. Krugman suggested re-asserting the split between investment banking and retail banking. The ongoing structural measures to introduce limitations on banking such as the US Volcker rule, the UK's Vickers ring-fence, and the EU's Liikanen proposal, which envisage creating a functional separation of operations, were all advanced as a reaction to the inadequate management of excessively risky speculative investments by deposit-taking banks.

Though there are historical examples of a split between investment banking and retail banking, as in the USA since the early 30's, our assumption is that it is more difficult to undertake the separation of speculative operations from the deposit-credit activities of the banks with an appropriate control, than to introduce a proper taxation on speculative activities. It is even more so at times of spectacular intensification of speculative activities. Even if it seems to be feasible, those speculative activities will be switched to the shadow banking system, which in its turn is still harder to control..

The global institutions are trying to catch up. The Basel committee on Banking Supervision published a new standard revising the prudential treatment of banks' investments in the equity of funds within the Basel capital framework. This year, it is set to be applied to banks' equity investments in all funds (e.g. hedge funds, managed funds and investment funds) [Basel Committee, 2013]. Still, it is extremely difficult to make banks reduce their speculative activities and thus lessen risks posed to the financial system. Why not let the banks do the job themselves, creating a substantial buffer outside of their books which would be paid for by the banking community?

One of the most suitable tools for this role seems to be the Financial Transaction Tax (FTT), according to many analysts [Baker, 2016]. However, arguments for its implementation have yet to achieve critical mass. The FTT is a fee charged on financial institutions for certain financial operations they carry out. This may concern stocks, bonds, shares, derivatives or other investment vehicles. Proposed means of implementing such a tax vary - by the residence of the investor or of the issuer, or by the asset's origin, for example. It is essential that the place of the operation does not matter, which decreases the attractiveness of offshore jurisdictions with regard to this type of operations.

The common argument stopping countries from introducing a FTT is that it would risk reducing the turnover of the financial sector and a number of financial institutions would flee to non-taxed exchanges. However, the tax rate is too minimal to really divert businesses from being registered in a national market or to make a visible impact on their activities. The FTT mostly does not exceed a few tenths (or even hundredths) of a percent of the value of any given transaction. It is possible to split the tax between the seller and the buyer. Among other negative consequences, the introduction of a FTT would likely lead to a reduction in investment. Some experts dispute the very idea of taxing such operations [PWC, 2012]. The use of the FTT can lead to a contraction not only in speculative trade, but also in transactions made by brokers with non- speculative purposes. An increased cost of operations may cause concern among governments as they assume investors might be less willing to buy state bonds due to a new taxation fee. Traders and investors may also move overseas if the tax is introduced in their country. Although, as mentioned above, the country of operation is not critical for the collection of the tax, bankers may find loopholes. 
The additional funds from the FTT received by the state or by an international organization (if the Fund is governed globally, which, in our opinion, is the preferable option) are primarily considered an advantage of this regulation. Such a tax could have empowered the G-20 (or the IMF) with the necessary financial resources to move forward faster with global financial sector reforms. For example, the US Congress proposed the introduction of a FTT and estimated getting $\$ 180$ billion from US banks alone between 2015 and 2023 (Fig. 1). A global tax could yield far more.

Table 1. Budget revenues from a tax on financial transactions in the US

\begin{tabular}{|c|c|c|c|c|c|c|c|c|c|c|c|c|}
\hline $\begin{array}{l}\text { Billions of } \\
\text { dollars }\end{array}$ & 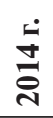 & 窉 & 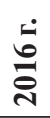 & $\stackrel{\dot{2}}{\overrightarrow{2}}$ & $\stackrel{\dot{\infty}}{\dot{乛}}$ & 完 & 灾 & $\dot{\widetilde{\Xi}}$ & 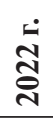 & ஷั & 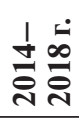 & 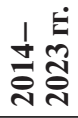 \\
\hline \begin{tabular}{|l|} 
Changes \\
in Revenues
\end{tabular} & 0 & 12 & 18 & 19 & 20 & 21 & 21 & 22 & 23 & 24 & 68 & 180 \\
\hline
\end{tabular}

Source: Congressional Budget Office. Staff of the Joint Committee of Taxation. November 2013. Available at: https://www.cbo.gov/budget-options/2013/44855

Another important theoretical point is that apart from money-raising arguments, the FTT serves as an appropriate market tool for reducing incentives for excessive speculation. It is unrealistic to expect that the use of the FTT will dramatically cut the number of short-term and highly-speculative securities trading, as the rate of the tax would be minimal at the initial stage of its introduction. However, the motivation for speculative activities might at least be a bit lower. That would be a very important sign for the bankers. The FTT has significant advantages over other taxes on financial activities, as it is relatively easy feasible and difficult to avoid. For the brokers specializing in high-frequency trade, for example, it is technically difficult to conduct operations from outside their respective countries because computer proximity to the Stock Exchange is critical.

Still another argument is that the FTT, by reducing systemic risks, contributes to sustainable economic growth. While there is growth, the volume of the rescue funds and thus their ability to safeguard financial stability will steadily increase. Justifying the introduction of the tax, J. Tobin pointed out another positive effect of the FTT on the economy. If a decrease in speculation activity occurs alongside a lowering of excessive profit margins, it makes careers in finance less attractive for active, intelligent and educated professionals. This could result in other sectors such as medicine, science or traditional industry attracting more and more talented people, redirecting the economy towards industrial growth.

Additionally, the FTT could be vital because of its special, deep-rooted effects, which are worth noting with regard to this study. This form of taxation could contribute (though modestly, but still) to a more equitable income distribution and a slowdown in the disproportional concentration of wealth. As described in the works of Thomas Piketty, the problem is high on the global agenda [Piketty, 2014]. Research shows that levying an FTT has a progressive effect. Roughly, 3/4 of the funds collected are ultimately paid by taxpayers in the highest income quintile and more than 40 percent falls 
on the top 1 percent [Burman, Gale and others, 2015]. One major step to socialize the FTT's mechanism could be the introduction of smart accountability systems. Special conditions could be applied to pension funds, and small companies or firms engaged in socially responsible activities could receive exemptions.

Finally, the bankers themselves and not the taxpayers would bear the financial responsibility for bailing out troubled financial institutions during a crisis, shifting the burden of the emergency bailouts away from the taxpayers, thus bearing the costs associated with extreme financial risk which are often unjustly shifted to individual taxpayers.

While nations continue to debate the merits of an FTT, the issue of practical implementation remains a sticking point. In 2011, several EU member states, including Austria, Belgium, France, Germany, Italy and Spain, put forward the idea of a common FTT for the European Union. In December 2012, the European Parliament voted for the proposal, which had been supported by eleven EU members. In January 2013, the European Council approved the introduction of the FTT. That was a very significant first move to implement the FTT globally. The impact of the EU's soft power has played an important role with respect to many other initiatives. It could be the case this time as well. The bank support fund created with the FTT disbursements could become a clever instrument to assure financial stability. The EU Council considered the introduction of the FTT to avoid shifting the burden for bailouts to taxpayers, as happened during the global financial crisis of 2008, when the US financial sector bailout launched a string of protests. A FTT on the banking system appears to be a fair way to assure more just financial regulation. Once introduced in the EU, other countries might wish to follow and to have such an instrument as well.

Still, diverging opinions remain, even at the highest political levels, on how to make use of such a tax in a more effective way. This article further develops the arguments in favor of the FTT. [Zuev, Nevskaya, 2018] In May 2014, ten out of the initial eleven participating member states (Slovenia abstained) agreed to seek a tax on equities and derivatives by 2016. In December 2015, however, Estonia decided to opt out, considering that the cost of collecting the tax would surpass the revenues (according to our calculations, this is not the case). Nevertheless, on March 16, 2016, the Republic of Estonia completed the formalities required to leave the enhanced co-operation on FTT. The FTT issue came to a standstill in the EU Council. The EU Economic and Financial Affairs Council decided that work would continue during the second half of 2016 between the remaining ten participants. Concerns arose over the cost efficiency of FTT collection. In February 2017, German Finance Minister Wolfgang Schaeuble said that implementation of the proposed European financial transaction tax was hindered by increasing demands for exemptions [Bloomberg, 2017].

Setting up a common EU system for the taxation of financial transactions is a method of ensuring the banks make a fair contribution to compensate for the cost of overcoming financial crises, since these banks have received substantial amounts of government support. The deadline to implement the agreement was shifted several times. The United Kingdom, as in many other cases, makes it clear that special protective measures must be used if damage is done to its market [Maurice, 2015]. The UK 
in general was not so much against the tax in principle. The country thought it would never work unless the tax was levied globally by the G20. The authors of this article share this view to a certain extent, without over-exaggerating the negative effect that London as financial center would experience if it lost out to New York or Singapore.

Taking into consideration the remaining lack of unity on the issue, the EU so far is undermining the introduction of the FTT in the rest of the world. However, the opposite could prove true as well: if the tax is implemented in the EU, the critical mass necessary for its transformation into a truly global instrument of regulation could be formed.

The idea of the introduction of the FTT at a global level was raised by the G20 in 2008 and received the support of the majority of member-states at that time. It was unfortunate that in 2010 at the summit in Toronto the proposal was shelved. It was a surprise, as currently 16 of the 20 members of the G20 use different types of taxes with similar effects to the FTT. The most widespread types of taxes resembling the FTT are a tax on trading in large companies' shares, the EU tax on short sales and sovereign credit default swaps (CDRs), and taxes aimed at high-frequency trading (for example, in France it is a tax on cancelled orders, in Italy - a tax on modified orders). Globally, more than 30 countries use different variations of the FTT, applying a rate of 0.1 to $0.5 \%$. Companies which apply various financial taxes include the United Kingdom, France, Belgium, Greece, Hong Kong, Switzerland, Australia, and South Korea.

In Europe, social justice considerations were taken into account during the implementation of the FTT; the mechanism provides countries with the opportunity to make exemptions for different categories of persons and institutions. For example, in Italy the tax on transactions with shares of national companies and derivatives is not applied to companies operating in 'socially meaningful' and 'ethical' spheres [Hemmelgarn, Nicodeme et al., 2015]. The selective application of financial operations taxes should be an additional tool to consider when developing socially-oriented adjustments to financial regulation.

The current UK FTT system didn't prompt investors to flee the country because its application isn't related to the investor's residence, as was the case with the Swedish tax [Seely, 2014]. Thus, the unification of those taxes could have been convenient for everybody [Hemmelgarn, Nicodeme et al., 2015]. The implementation of a unified tax policy renders irrelevant the argument that the introduction of the FTT would present an additional burden for financial institutions. This argument seems to be irrelevant anyway, as the rate of taxation is very small. In all the states that have adopted variations of the FTT, as well as in most other countries (e.g. in the EU), popular support for the implementation of the tax is high.

The transposition of the FTT from the national level to a regional or global level is a prerequisite for the actors' acceptance of the tax. The cases of Estonia and Sweden demonstrate that the introduction of the tax on a unilateral basis by a small country alone may be not efficient. Most of the studies reveal that a FTT with a broad (global) tax base provides greater revenues [Schaefer, 2015]. The necessary synergies appear to materialize best when the tax is levied at the global level. 
In order to efficiently socialize the impact of the FTT's introduction, it is critical to define exact patterns for how states must spend the funds they raise, in order to circumvent the necessity of future bail-outs. We do not have crises all the time. Thus, the Fund could be used for some other purposes if there is no financial crisis. The EU countries' experience demonstrates that it is possible to proclaim "far reaching" goals, such as using the new funds to grant aid to the poorest countries. One way of spending could be to finance growth-enhancing projects and create an international "safety cushion" for the banks, which could serve as an incentive for them to follow the initiative. In our view, it would be much easier to gain supporters for the idea of introducing the FTT within the banking community, had it been announced that the Basel 3 norms on capital requirements would be relaxed for countries which had created the fund for assisting banks in trouble. Creating the fund would mean giving banks more flexibility in their credit policies, as the fund, once operational, could provide the necessary assistance at the expense of the banks themselves. In this case, one could expect a positive effect on banking community leaders to stimulate them to accept the taxation.

Using a financial transaction tax as a tool to discourage excessive speculation without hampering any other activity seems to be socially responsible measure which would promote financial stability at the same time.

\section{Debt: do not use it widely}

Financial globalization and fast growing debt levels mean that crises can spread far more quickly and widely, contributing to financial shocks. These are detrimental to global economic growth and resilience, presenting a major challenge for the implementation of the SDGs. According to the IMF Fiscal Monitor, published in October 2016, the global debt of the non-financial sector has reached an unprecedentedly high level of $225 \%$ of the world's GDP. According to the authors of the report, consensus on what level of debt could be considered high has not been achieved yet. However, one need only imagine that every producer of goods and services in every country must work and spend nothing on food for 2 years in a row to make possible the repayment of the principal, not even the interest, of this debt. Obviously, it is impossible. From our standpoint, the situation continues to spiral out of control. The most alarming is that the global debt to GDP ratio exceeds its historic highs despite the absence of financial crises, unlike in 2008-2009 and 2014. During times of crisis, a record increase in indebtedness could be explained by the urgent need to rescue national economies with massive liquidity injections. What basic explanation can we provide for the current record levels of debt? Is it out of a habit? Is it because of the easy availability of funding? The desire to solve problems (of economic growth, asset acquisition) not via the time- and effort-consuming activity of making money, but using quick and easy borrowing in exchange for the promise to repay later? Another underestimation of policy risks without adequate deleveraging?

Two-thirds of global debt consists of private sector liabilities, which is an additional cause for concern. As soon as the government makes the decision to help national corporations during times of financial trouble by launching bailouts, private debt 
turns into public debt and adds substantially to the levels of governmental indebtedness, which was the case in the aftermath of the 2007-09 global crisis.

Emerging markets' nonfinancial corporate debt surpassed the \$26 trillion mark in the first half of 2016, according to the Institute for International Finance. In its turn, the corporate debt level of most nonfinancial companies in emerging economies rose from \$4 trillion in 2004 to \$18 trillion in 2014 [IMF, Global Financial Stability Report, 2016].

Demand for emerging market debt can be explained by higher yields and low and or even negative bond yields in developed economies. Brexit was another important factor in diverting investment flows from the developed economies. International investors have put more than $\$ 18$ billion into dollar-denominated emerging market bond funds since the United Kingdom voted to leave the EU. China and Saudi Arabia are the leading developing market sovereign debt issuers. That large volume of corporate debt could be seen as exerting additional pressure on government financing. In the event of low economic activity, if a government helps national corporations, its debt burden only increases further. Billionaire investor George Soros has expressed concern about China increasing its volume of debt. The rise in new borrowing suggests that the Chinese government is prioritizing growth instead of controlling debt. Stocks and bonds maintain a positive correlation, especially when investors are unsure about the prospects of stocks.

Thus, we have every reason to consider the levels of non-financial sector debt jointly, public and private. Excessive private debt is widely considered as a potential risk to economic stability and growth. On the other hand, there is another concern: that a private deleveraging process could stifle the delicate economic recovery.

Surprisingly enough, little attention is paid to government debt, which amounts to the remaining one third of global debt. While increasing control is exercised over private sector debt and the borrowing of banks (see part 1 and 2 of the article), there is virtually no regulation of government debt. Indeed, the regulation aimed at prevention of bankruptcy among individuals, firms and banks becomes more advanced and rigid. On the contrary, governments are almost free in their borrowing: no limits, no regulation, no control. With minor exceptions like in case of sovereign debt ratings procedure. Until recently, most experts, when assessing risks to global financial stability, took all types of debt into consideration except sovereign debt. Does it mean we don't have to worry about the ability of the states to repay their lenders?

The cases of small European countries such as Greece, Ireland, Portugal, and some bigger countries (Spain and Italy) during the recent global financial crisis demonstrated that the risks are high and real. Only the provision of financial help from the European Central Bank, IMF and the EU, such as the 240 billion euros lent to Greece in 2010 and 2012 allowed the EU to solve the problem, and the measure was only partially successful. Even extraordinary financial injections failed to help the country address its imbalanced finance, and seven years after the launching of massive external emergency lending, even bigger countries, like Italy, remain exposed to financial stability risks. We can generalize that in Europe, insufficient EU-level debt regulation can be identified as a common feature. The lack of rigid regulation led to a high level of indebtedness within certain individual countries, which was detrimental to the system as a whole. The com- 
mon feature for the EU countries could be identified as insufficient supervision and a lack of regulation from the governing bodies of the Union. The high indebtedness of the member states was at least in part the result of the incoherent system.

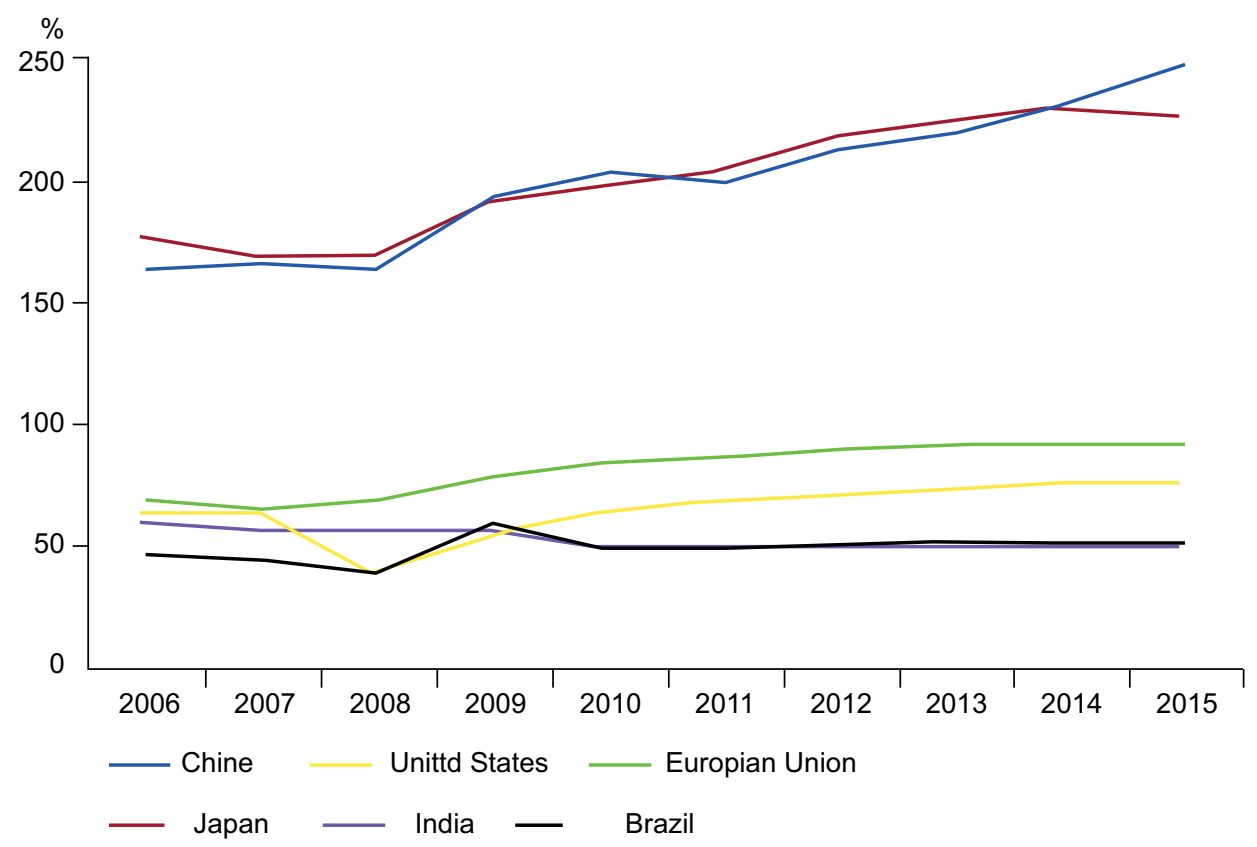

Fig. 1. Global Debt Sending a Warning to the Market

Source: IMF, OECD

Let us look at it in another way. If a government is over-indebted, public budget cuts to vital services are inevitable, which constitutes a sacrifice in human well-being and long-term growth prospects. Moreover, in a globalized world, it's easy for one country's over-indebtedness to have spillover effects that affect regional or even global markets, as the recent Greek financial crisis demonstrated [Motoko Aizawa, 2016].

We'll try to summarize arguments in favor of the regulation of government debt:

1) Excessive levels of government debt often stifle economic growth.

The central banks of developed economies are putting more money into their respective economies in the form of quantitative easing (QE). Governments across the world are issuing more debt to fund their fiscal deficit. By issuing debt, they are aiming to increase their fiscal stimulus and accelerate economic activity in order to boost economic growth. When stimulating the economy by using fiscal policy, as countries did during the crisis and post-crisis period, governments overwhelmingly resort to debt financing. Some experts consider an increase in government debt to be an incentive for economic recovery and growth. Notably, the econometric models presented in the work of Jordà, Schularick, and Taylor suggest "that fiscal policy can significantly reduce the output cost of a financial crisis, provided that fiscal buffers are available prior to the crisis" [Jorda, Schularick, Taylor, 2016]. 
However, once it becomes excessive, government debt turns into an obstacle to economic growth. Three groups of economists have independently shown that high government debt negatively affects long-term economic growth. The general explanation for this correlation is the following: when government debt exceeds a certain threshold, private investment activity tends to ebb due to the lower value of government guarantees, as well as a lower level of trust in the government. This ultimately lowers future profits and leaves no space for future growth. According to empirical studies across advanced economies, the worst effects occur when the government debt to GDP ratio reaches a level of $90 \%$. However, recent empirical evidence casts doubt on that level. Studies by Manmohan Kumar, Jaejoon Woo (IMF) [Kumar, Woo, 2010] and by Carmen Reinhart, Vincent Reinhart and Kenneth Rogoff (National Bureau of Economic Research) [Reinhart, Reinhart, Rogoff, 2012] have illustrated that once a country's government reaches higher-debt status, the economy tends to experience a slowdown in economic growth. Yet another study was carried out by Stephen Cecchetti, Madhusudan Mohanty, and Fabrizio Zampolli (the Bank for International Settlements), who found that high government debt had nearly the same negative effects on economic growth [Cecchetti, Mohanty, Zampolli, 2011].

Despite being challenged as questionable by some experts, such as Ugo Panizza and Andrea F. Presbitero (UNCTAD) [Panizza, Presbitero, 2014], the idea of potential harm to economic growth from an overleveraged government is gaining popularity among economists. Some have established that excessive debt levels lead to a slowdown in growth even in the absence of an economic crisis. The reason for this is that highly indebted borrowers will have to reduce investments sooner or later, and subsequently might even reduce consumption as they become less able to service their debt. Lenders will be less inclined to extend new loans to them.

One of the most popular ratios for sovereign debt, which compares it to GDP, has a certain defect. The use of the GDP seems unrelated, as such an approach ignores the asset side of the balance sheet, which matters when evaluating repayment capacity. Assets, like incomes, can be used to build up repayment flows. An alternative methodology is to use something akin to the sustainability criterion proposed by Arrow and others [Arrow, Dasgupta, Goulder and others, 2004] where private debt is assessed as sustainable whenever net asset worth follows a non-decreasing trend. The concept requires debt to evolve in line with the value of assets, corrected for valuation effects. A similar approach was shared later by Cuerpo and others [Cuerpo, Drumond, Lendvai, 2015] .

Some studies have identified the effect on growth of public debt. ${ }^{6}$ Unfortunately, as already stated, there is no consensus on the threshold at which debt levels (private or government) begin to matter for growth or trigger deleveraging. Our assumption is that

${ }^{5}$ Cuerpo, C., I. Drumond, J. Lendvai, P. Pontuch, and R. Raciborski. 2015. "Private Sector Deleverage in Europe." Economic Modelling 44: 372-83.

${ }^{6}$ See, for example, Krugman, P. 1988. "Financing vs. Forgiving a Debt Overhang." Journal of Development Economics 29 (3): 253-68.; Reinhart, C. M., and K. S. Rogoff. 2010. "Growth in a Time of Debt." NBER Working Paper 15639, National Bureau of Economic Research, Cambridge; Baum, A., C. ChecheritaWestphal, and P. Rother. 2013. "Debt and Growth: New Evidence for the Euro Area." Journal of International Money and Finance 32: 809-21. 
the levels of debt currently revealed should start to be considered excessive, potentially endangering global financial stability.

2) Excessive levels of government debt might cause potential harm to global financial stability.

Numbers speak volumes. If we look at the scale of government debt compared to GDP, the rapid increase is striking (see the Graph 1 below).

However, a comparison with GDP doesn't provide the complete picture, simply because the whole value of GDP couldn't be spent on repaying the debt. In principle, one could use government debt to GDP ratios to reach certain judgments about the situation, but this approach ignores the asset side of the balance sheet, which is crucial for the adequate evaluation of repayment capacity. The capacity to pay back debt is most important in terms of sustainable growth. An alternative would be to compare government debt to some other indicators, such as gross national savings, or the total revenues of the central government. As we can see from Graph 3, government debt in G20 dramatically exceeds government revenues and national savings, and the trend is still upward. The government debt to official reserves ratio is quite similar: it decreased during the economically prosperous period of 2000-2006, but started to grow again after the recent financial crisis, and in the year 2015 reached the level of 715.88, which means that we could not rely on official reserves in the event of an emergency.

It can easily be asserted that the extremely high level of government debt among major economies poses a threat global financial stability. Governments, as lenders of last resort, are expected not just to provide public goods and confront the economic cycle, but also to provide financial assistance in the form of loans to banks and the non-financial sector in the aftermath of financial shocks. If systematically important banks and companies face the risk of bankruptcy again, governments will be expected to help them. But who will help these governments as they too, one by one, face the risk of default?

Obviously, international financial institutions such as the Word Bank and IMF form a kind of a financial buffer that plays a crucial role in the event of such emergencies. Despite being criticized for its insufficient efficiency and agility, the IMF managed to help countries in need during the recent financial crisis. Nevertheless, it is obvious that the Fund's resources, measuring in the billions of US dollars, are no match for global government debt, which measures in the trillions (see the Table below), and in the event of a global government debt crisis, the IMF can't be expected to assure the financial stability of the world. After the financial crisis of 2007-2008, the global financial system has undergone several reforms aimed at improving its stability and enhancing its effectiveness. But even though established institutions are accumulating financial resources and new institutions are being developed, the capacity of the global financial system still hasn't responded adequately and proportionally to the exponentially increasing risks.

3) Excessive levels of government debt clash with the idea of sustainable and inclusive economic growth.

According to the 2030 Agenda for Sustainable Development, the G20 countries are committed to "ensure that no one is left behind in our efforts to eradicate poverty, 


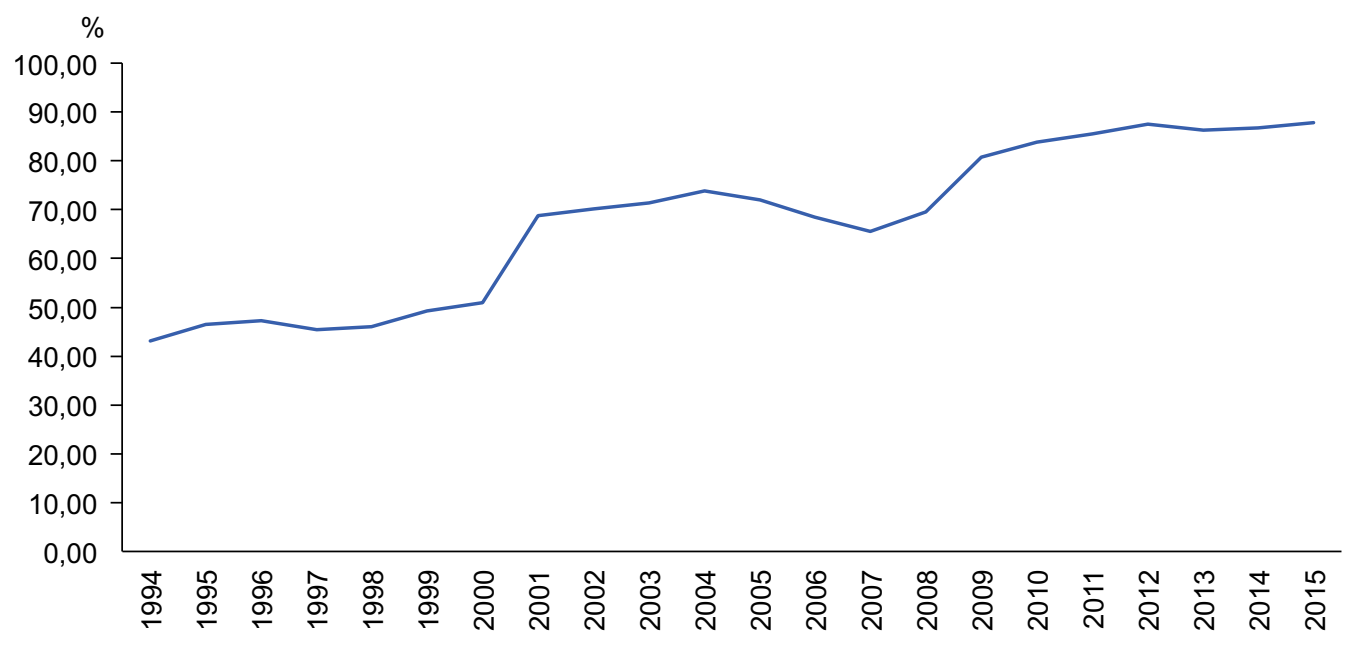

Fig. 2. Gross Government Debt to GDP Ratio for G20 countries

Source: calculated by authors according to IMF Data

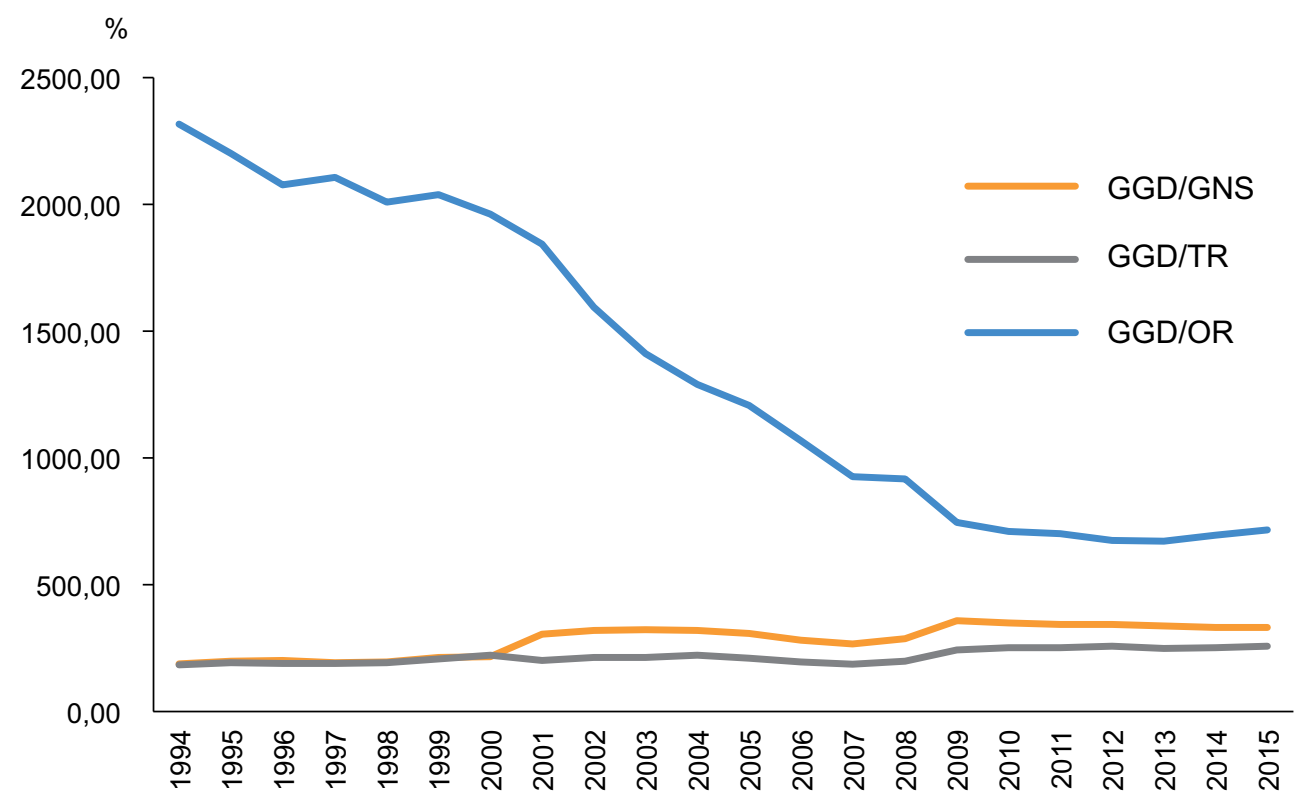

Fig. 3. Public Debt as a $\%$ of Gross National Savings and Government Total Revenues

Source: calculated by authors according to IMF Data.

achieve sustainable development and build an inclusive and sustainable future for all." Nevertheless, continuously increasing government borrowing at the expense of future development does not conform to the goal of sustainable growth declared by G20. Additionally, it contradicts with the idea of inclusiveness that implies considering the interests of all social groups, because, ultimately, citizens must pay for government debt 
Table 2. Government debt to IMF resources ratio (total value of SDRs)

\begin{tabular}{|l|l|l|l|l|l|}
\hline Year & Ratio & Year & Ratio & Year & Ratio \\
\hline 1994 & 4746 & 2004 & 8711 & 2010 & 7181 \\
\hline 1996 & 5882 & 2005 & 9141 & 2011 & 8068 \\
\hline 1998 & 3860 & 2006 & 9338 & 2012 & 8383 \\
\hline 2000 & 4582 & 2007 & 10020 & 2013 & 8465 \\
\hline 2001 & 6162 & 2008 & 11541 & 2014 & 8734 \\
\hline 2003 & 7511 & 2009 & 12747 & 2015 & 8366 \\
\hline
\end{tabular}

Source: calculated by authors according to IMF and World Bank Data

restructuring. Indeed, if governments are bankrupt, citizens would suffer most again, as in the case of the 2008 financial crisis and bank bailout. Socially responsible global financial governance should take into consideration the seriousness of the governmental debt issue in a similar manner to how it treated the bank's resilience issue.

That being said, a need for reigning in government borrowing must be acknowledged as an important objective. Some experts and some institutions have started to acknowledge the relevance of the issue. The talk is about the global governance gap in the key area. Motoko Aizawa made a point we fully share, stating in his study on global debt that we currently lack an effective insolvency apparatus that could resolve sovereign debt crises in a fair, speedy and sustainable manner [Motoko Aizawa, 2016]. The pioneer in dealing with the issue is the European Union, which has already taken some steps to establish government debt regulation. These are the introduction of the Maastricht criteria, the implementation of the budget coordination mechanism, and the development of stability and convergence programs. We believe such practices should be taken by the G20 countries, which account for approximately $86 \%$ of global GDP and $87 \%$ of global government debt. ${ }^{7}$ We advance the idea that the meaningful solution to the global public debt governance issue might be the introduction of an agreement akin to the Basel Agreements in banking that have already proved their effectiveness.

Today international institutions and experts explore ways to ensure responsible lending and borrowing by G20 governments. As suggested, responsible lending, in accordance with 2012 UNCTAD Principles on Promoting Responsible Sovereign Lending and Borrowing and the 2011 EURODAD Responsible Finance Charter, could protect both debtor and creditor nations.

However, in our view, it's unrealistic to expect individual governments to engage in and promote responsible lending and borrowing policy. Imagine a government in desperate need of funds that refuses a gracious offer from an outside lender to provide the necessary financing... The notion of convincing lenders that they have to be more responsible is also illusionary. Given the nature of the activity, they are willing to get back their money and profits anyway. You do not have to convince them or guide them according to any type of codex. The only thing that matters is that a high level of risk

\footnotetext{
${ }^{7}$ Calculated by authors according to IMF Data.
} 
awareness is required. The more the lenders realize that global debt levels have reached an untenable point, the more prudent they will be in their lending policies.

Additionally, in terms of the Sustainable Development Goals, it is reasonable to assess whether a country's debt payments are preventing the financing of human and environmental needs. The existing IMF-World Bank Debt Sustainability Framework should be broadened and applied to advanced and emerging economies, rather than just to low-income states as it is now. Their extremely high levels of debt endanger global financial stability.

We believe the G20 should make a significant contribution to increasing public awareness of risks that come from high debt levels for both developed and developing countries. The most critical indicator for investors is trust. Once investors lose their trust, they stop giving money. Consequently, the more people are aware of risks thanks to the G20's effort, the more rational and efficient their investment activity will become. Lack of monitoring is another issue the G20 could try to tackle. Who will reign in countries which opt to pursue insane borrowing policies? The need is there for the introduction of comprehensive public debt mechanism, based upon the early warning system of global financial supervision.

\section{Conclusion}

Rapidly growing debt levels, both private and public, and both in the banking and nonfinancial sector, present a real threat to global financial stability. In the age of financial globalization, every crisis can be expected to spread far more quickly and widely than ever before, contributing to financial shocks around the world. This untenable level of borrowing is detrimental to global economic growth and resilience, and must be addressed if the international community hopes to accomplish the development goals shared by the world's largest economies and the United Nations.

It would be incorrect to say that the issue is not being considered. It is. But the way it is being addressed is far too "narrow' in scope, given the potential consequences. The problem requires much broader consideration: at the global level; with enough attention paid to both private and public debt. International efforts have been made to address and upgrade bank capital requirements, but no major sector-financed fund exists to help them; this could be achieved with the introduction of the FTT at the G20 level. While such a fund exists for governments in the form or the IMF, the monetary resources available lag far behind rapidly-growing public and non-financial sector debt levels.

After the start of the global financial crisis, the amount of public debt in advanced economies and some systematically important emerging economies rose rapidly, presenting a real threat to the global financial stability and economic development. Governments tend to borrow without limits, but this can't continue endlessly. Economists and policy makers must tend to this issue in earnest due to its high relevance. In a globalized world, if major economies fail under the burden of public debt, there will be no adequate response and assistance from the international financial institutions. Then real economic chaos will ensue, compared to which the global financial crisis will be regarded as a kind of "slight instability." 


\section{References}

Baker D. (2008) The Benefits of a Financial Transaction Tax. Washington, DC.: Center for Economic and Policy Research.

Baxter L.G. (2011) Exploring the WFO Option for Global Banking Regulation. Globalization \& Governance, pp. 113-124.

Brummer C. (2012) Soft Law and the International Financial System: Rule Making in the 21st Century. New York: Cambridge University Press.

Bruno V., Song Shin H. (2014) Cross-Border Banking and Global Liquidity. Bank for International Settlements. August. Available at: http://www.bis.org/publ/work458.pdf (accessed 17 January 2017).

Burman L., Gale W. et al. (2015) Financial Transaction Taxes in Theory and Practice. Urban Institute \& Brookings Institute. June. Available at: http://www.taxpolicycenter.org/PDF/2000287-Financial-Transaction-Taxes-in-Theory-and-Practice (accessed 17 January 2017).

Cecchetti S.G., Mohanty M.S., Zampolli F. (2011) The Real Effects of Debt: BIS Working Paper 352. Bank for International Settlements, Basel.

Gros D. (2013) The Problems of Basel Principles Usage in the EU. Banking Union with a Sovereign Virus: The Self-serving Treatment of Sovereign Debt. Intereconomics, vol. 48, iss. 2, pp. 93-97.

Hemmelgarn T., Nicodeme G. et al. (2015) Financial Transaction Taxes in the European Union. European Commission taxation papers: Working paper no 62.

Jordà O., Schularick M., Taylor A.M. (2016) Sovereigns Versus Banks: Credit, Crises, and Consequences. Journal of the European Economic Association, no 14 (1), pp. 45-79.

Keynes J.M. (1936) General Theory of Employment, Interest and Money, pp. 159-60. Harcourt Brace, New York.

Manmohan S. Kumar and Jaejoon Woo (2010) Public Debt and Growth: IMF Working Papers, WP/10/174.

Maurice E. (2015) EU Financial Transaction Tax on life Support. EU Observer. 8 December. Available at: https://euobserver.com/economic/131435 (accessed 17 January 2017).

New York Times (2016) The Need for a Tax on Financial Trading. 28 January. Available at: http://www. nytimes.com/2016/01/28/opinion/the-need-for-a-tax-on-financial-trading.html (accessed 17 January 2017).

Panizza U., Presbitero A.F. (2014) Public Debt and Economic Growth: Is There a Causal Effect? Journal of Macroeconomics, no 41, pp. 21-41.

Piketty T. (2014) Capital in the 21st century. Harvard University Press.

Reinhart C.M., Reinhart V.R., Rogoff K.S. (2012) Public Debt Overhangs: Advanced-Economy Episodes since 1800. Journal of Economic Perspectives, no 26 (3), pp. 69-86.

Tobias A. (2014) Financial stability Policies for Shadow Banking. Staff Report, Federal Reserve Bank of New York, no 664, p. 9.

Tsingou E. (2003) Transnational Policy Communities and Financial Governance: The Role of Private Actors in Derivatives Regulation. P. 8. Available at: http.: warwick.ac.uk/2009/1/WRAP_Tsingou_wp11103.pdf (accessed 17 January 2017).

Underhill G., Zhang X. (2008) Setting the Rules: Private Power, Political Underpinnings, and Legitimacy in Global Monetary and Financial Governance. International Affairs 84 (3), pp. 535-554.

Zuev V., Nevskaya A. (2018) Governing the Gaps in Global Banking. Accountability for Effectiveness in. Global Governance (J.J. Kirton and M. Larionova (eds)). Abingdon: Routledge. 


\title{
Глобальная долговая проблема и проблема устойчивости мировой экономики ${ }^{1}$
}

\author{
В.Н. Зуев, Е.Я. Островская, Е.С. Фролова
}

Зуев Владимир Николаевич - д.э.н., профессор кафедры торговой политики Национального исследовательского университета «Высшая школа экономики»; Российская Федерация, 101000, Москва, ул. Мясницкая, д. 20; E-mail: vzuev@hse.ru

Островская Елена Яковлевна - к.э.н., доцент департамента мировой экономики Национального исследовательского университета «Высшая школа экономики»; Российская Федерация, 101000, Москва, ул. Мясницкая, д. 20; E-mail: eostrovskaya@hse.ru

Фролова Екатерина Сергеевна - ассистент департамента мировой экономики Национального исследовательского университета «Высшая школа экономики»; Российская Федерация, 101000, Москва, ул. Мясницкая, д. 20; E-mail: esfrolova@icloud.com

Статья посвящена рассмотрению проблем растущей задолженности и финансовых рисков сквозь призму концепции устойчивого развития и экономического роста. Данной концепции уделяется все больше внимания в связи с острой необходимостью координации действий на национальном и международном уровнях. Господствующие экономические теории недооценивают возможные риски. Несмотря на большое количество мер, принятых для обеспечения финансовой стабильности в мире после глобального финансового кризиса, риски остаются высокими. Это связано в первую очередь с появлением новых угроз и вызовов для устойчивости глобальной финансовой системы. Рассмотрев нововведения в области банковского регулирования с точки зрения финансовой устойчивости и социальной справедливости, авторы приходят к выводу, что направление вектора реформ задано верно, но глобальная финансовая система остается пока недостаточно резистентной к новым вызовам. Предложенная авторами идея заключается в том, что введение ведущими экономиками мира налога на финансовые операции в качестве инструмента понижения избыточной спекулятивной активности не приведет $\kappa$ замедлению развития экономики, чем аргументируют свою позицию противники данного налога. Наоборот, введение налога на финансовые операции будет выполнять двеважные функции:станет социально ответственной мерой и снизит уровень угроз финансовой стабильности. Авторами также выдвинуто предположение относительно того, что все более серьезный вызов мировой финансовой стабильности и устойчивому росту представляет постоянно растущая задолженность нефинансового сектора. Доминирующие оценки степени угроз беспрецедентной задолженности для мировой экономики в своем большинстве неадекватны, а эффективных и социально справедливых мер по ее сокращению не выработано. Если в условиях глобализации крупные экономики не выдержат долговой нагрузки, международные финансовые институты будут не в состоянии предложить адекватную поддержку. Нарастающие финансовые дисбалансы создают риски обеспечения экономической стабильности, рассматриваемой авторами в качестве ключевого фактора для реализации Целей устойчивого развития, сформулированных ООН в 2015 г. в Программе устойчивого развития 2030.

Ключевые слова: долги нефинансового сектора; финансовая стабильность; устойчивый и инклюзивный рост; урегулирование долговой проблемы; налог на финансовые операции

Для цитирования: Зуев В.Н., Островская Е.Я., Фролова Е.С. Глобальная долговая проблема и проблема устойчивости мировой экономики // Вестник международных организаций. 2017. Т. 12. № 4. С. 68-90. DOI: $10.17323 / 1996-7845-2017-04-68$

${ }^{1}$ Статья поступила в редакцию в июле 2017 г.

Модифицированная версия статьи была размещена в июне 2017 г. на сайте «Группы 20» "Insights - literature from the Think tanks" в ходе подготовки к саммиту «Группы 20» в рамках исполнения председательских функций Германией в 2017 г. Режим доступа: http://www.g20-insights. org/related_literature/vladimir-zuev-elena-ostrovskaya-ekaterina-frolova/ (дата обращения: 17.10.2017). 


\section{Литература}

Baker D. (2008) The Benefits of a Financial Transaction Tax. Washington, DC.: Center for Economic and Policy Research.

Baxter L.G. (2011) Exploring the WFO Option for Global Banking Regulation // Globalization \& Governance. P. $113-124$.

Brummer C. (2012) Soft Law and the International Financial System: Rule Making in the 21st Century. N.Y.: Cambridge University Press.

Bruno V., Song Shin H. (2014) Cross-Border Banking and Global Liquidity // Bank for International Settlements. August. Режим доступа: http: // www.bis.org/publ/work458.pdf (дата обращения: 17.01.2017).

Burman L., Gale W. et al. (2015) Financial Transaction Taxes in Theory and Practice. Urban Institute \& Brookings Institute. June. Режим доступа: http: // www.taxpolicycenter.org/PDF/2000287-Financial-Transaction-Taxes-in-Theory-and-Practice (дата обращения: 17.01.2017).

Cecchetti S.G., Mohanty M.S., Zampolli F. (2011) The Real Effects of Debt: BIS Working Paper 352. Bank for International Settlements, Basel.

Gros D. (2013) The Problems of Basel Principles Usage in the EU. Banking Union with a Sovereign Virus: The Self-serving Treatment of Sovereign Debt // Intereconomics. Vol. 48. Iss. 2. P. 93-97.

Hemmelgarn T., Nicodeme G. et al. (2015) Financial Transaction Taxes in the European Union. European Commission taxation papers. Working paper No. 62.

Jordà O., Schularick M., Taylor A.M. (2016) Sovereigns Versus Banks: Credit, Crises, and Consequences // Journal of the European Economic Association. No. 14 (1). P. 45-79.

Keynes J.M. (1936) General Theory of Employment, Interest and Money. Harcourt Brace, New York. P. 159_ 160 .

Manmohan S.K., Woo J. (2010) Public Debt and Growth: IMF Working Papers, WP/10/174.

Maurice E. (2015) EU Financial Transaction Tax on life Support // EU Observer. 8 December. Режим доступа: https: // euobserver.com/economic/131435 (дата обращения: 17.01.2017).

New York Times (2016) The Need for a Tax on Financial Trading. 28 January. Режим доступа: http: // www. nytimes.com/2016/01/28/opinion/the-need-for-a-tax-on-financial-trading.html (дата обращения: 17.01. 2017).

Panizza U., Presbitero A.F. (2014) Public Debt and Economic Growth: Is There a Causal Effect? // Journal of Macroeconomics. No. 41. P. 21-41.

Piketty T. (2014) Capital in the 21st century. Harvard University Press.

Reinhart C.M., Reinhart V.R., Rogoff K.S. (2012) Public Debt Overhangs: Advanced-Economy Episodes since 1800 // Journal of Economic Perspectives. No. 26 (3). P. 69-86.

Tobias A. (2014) Financial stability Policies for Shadow Banking. Staff Report, Federal Reserve Bank of New York. No. 664. P. 9.

Tsingou E. (2003) Transnational Policy Communities and Financial Governance: The Role of Private Actors in Derivatives Regulation. P. 8. Режим доступа: http: warwick.ac.uk/2009/1/WRAP_Tsingou_wp11103.pdf (дата обращения: 17.01.2017).

Underhill G., Zhang X. (2008) Setting the Rules: Private Power, Political Underpinnings, and Legitimacy in Global Monetary and Financial Governance // International Affairs. Vol. 84 (3). P. 535-554.

Zuev V., Nevskaya A. (2018) Governing the Gaps in Global Banking. Accountability for Effectiveness in. Global Governance / J.J. Kirton, M. Larionova (eds). Abingdon: Routledge. 